\title{
Analisis Faktor-Faktor yang Mempengaruhi Kinerja Keuangan Lembaga Perkreditan Desa di Kabupaten Badung
}

\section{Anak Agung Sagung Indah Nareswari ${ }^{1}$ \\ Fakultas Ekonomi dan Bisnis Universitas Udayana, Indonesia}

\author{
I Ketut Budiartha ${ }^{2}$ \\ Fakultas Ekonomi dan Bisnis \\ Universitas Udayana, Indonesia
}

\begin{abstract}
Surel : indahnares98@gmail.com
ABSTRAK

Lembaga keuangan memiliki peran penting dalam meningkatkan perekonomian negara, salah satunya LPD. Penelitian ini bertujuan untuk menganalisis faktor yang mempengaruhi kinerja keuangan LPD di Kabupaten Badung. Jumlah sampel yang diambil sebanyak 87 LPD di Kabupaten Badung dengan metode probability sampling. Metode Pengumpulan data yang digunakan adalah metode survey dengan menyebarkan kuesioner. Teknik analisis yang dilakukan adalah regresi linier berganda. Hasil Penelitian ini menunjukkan bahwa prinsip good governance yaitu transparansi, akuntabilitas, responsibilitas, independensi, kewajaran serta kompetensi sumber daya manusia yang terdiri dari pengetahuan, keterampilan, dan sikap berpengaruh positif terhadap kinerja keuangan. Hasil Penelitian ini diharapkan mampu memberikan tambahan informasi bagi pihak-pihak yang berperan langsung dalam meningkatkan kinerja keuangan untuk menjalankan tugasnya dengan baik sehingga akan mampu menghasilkan kinerja keuangan yang berkualitas.
\end{abstract}

Kata Kunci: Kinerja Keuangan; Prinsip Good Governance; Kompetensi Sumber Daya Manusia.

\section{Analysis Of Factors Affecting The Financial Performance Of Village Credit Institutions In Badung District}

\begin{abstract}
Financial institutions have an important role in improving the country's economy, one of which is the LPD. This study aims to analyze the factors that affect the financial performance of LPDs in Badung Regency. The number of samples taken was 87 LPDs in Badung Regency with a probability sampling method. The data collection method used was a survey method by distributing questionnaires. The analysis technique used is multiple linear regression. The results of this study indicate that the principles of good governance, namely transparency, accountability, responsibility, independence, fairness and competence of human resources consisting of knowledge, skills, and attitudes have a positive effect on financial performance. The results of this study are expected to be able to provide additional information for parties who have a direct role in improving financial performance to carry out their duties properly so that they will be able to produce quality financial performance.
\end{abstract}

Keywords: $\quad$ Financial Performance; Good Governance Principles; Human Resources Competence.

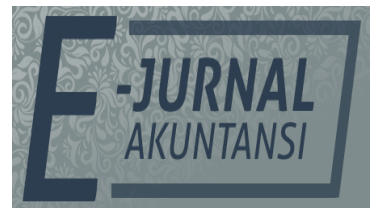

e-ISSN 2302-8556

Vol. 31 No. 10

Denpasar, Oktober 2021

Hal. 2621-2635

DOI:

10.24843/EJA.2021.v31.i10.p13

PENGUTIPAN:

Nareswari, A.A.S.I., \&

Budiartha, I.K. (2021).

Analisis Faktor-Faktor yang

Mempengaruhi Kinerja

Keuangan Lembaga

Perkreditan Desa di

Kabupaten Badung. E-Jurnal

Akuntansi, 31(10), 2621-2635

RIWAYAT ARTIKEL:

Artikel Masuk:

1 Maret 2021

Artikel Diterima:

26 Mei 2021

Artikel dapat diakses : https://ojs.unud.ac.id/index.php/Akuntansi/index 


\section{PENDAHULUAN}

Lembaga keuangan memiliki peran penting dalam meningkatkan perekonomian negara. Lembaga keuangan lokal telah berkembang di berbagai wilayah di Indonesia, seperti Badan Kredit Kecamatan (BKK) di Jawa Tengah, Lembaga Perkreditan Kecamatan (LPK) di Jawa Barat, Lumbung Pitih Nagari (LPN) di Sumatra Barat (Sadiartha, 2017). Lembaga keuangan mikro yang ada di Provinsi Bali adalah Lembaga Perkreditan Desa (LPD) yang terdapat di masing-masing desa adat/desa pekraman (Mahaendrayasa \& Putri, 2017). LPD adalah lembaga ekonomi desa yang berguna sebagai tempat pengumpulan dana, pemberian kredit, serta sumber pembiayaan dalam pembangunan di wilayah desa yang ada di Bali. Lembaga keuangan ini bertujuan untuk membantu Desa Pakraman dalam membangun perkeonomian lewat tabungan dan pemberian modal, serta membantu memberikan pelayanan jasa keuangan kepada masyarakat desa dengan prosedur yang sederhana, singkat, serta lokasi yang dekat dengan nasabah pedesaan (Anggayana \& Wirajaya, 2019). Kesederhanaan kaidah LPD tidak mengurangi manfaat yang didapatkan masyarakat dalam hal pelayanan dan menjangkau berbagai sektor usaha masyarakat (Sandraningsih \& Putri, 2015).

Kinerja keuangan dapat menggambarkan kinerja fundamental perusahaan (Paniagua et al., 2018). Kinerja keuangan merupakan prestasi kerja yang telah dicapai oleh perusahaan dalam suatu periode tertentu dan tertuang dalam laporan keuangan (Andriana \& Panggabean, 2017). Penilaian kinerja keuangan suatu organisasi memiliki kaitan yang erat dengan peningkatan laba, jika kinerja keuangan perusahaan berjalan dengan baik maka akan mempengaruhi peningkatan laba (Ozkan et al., 2016). LPD menggunakan kinerja keuangannya dalam menentukan klasifikasi Kesehatan LPD. Aspek keuangan berpredikat sehat mencerminkan bahwa kinerja keuangan LPD tersebut baik. Dasar penilaian LPD dalam menentukan tingkat Kesehatan LPD melalui pendekatan kuantitatif berdasarkan 4 faktor, yaitu, permodalan (capital), kualitas aktiva produktif (asset), rentabilitas (earning), dan likuiditas (liquidity). LPD yang kurang sehat umumnya dikarenakan permasalahan internal dalam kepengurusan LPD. Makadari itu diperlukan suatu sistem tata kelola yang baik (good governance) untuk meminimalisir permasalahan-permasalahan pada suatu LPD yang dapat mempengaruhi kinerja keuangan LPD, karena Kinerja keuangan merupakan cermin dari tingkat kesehatan suatu perusahaan (Nuryana \& Surjandari, 2019).

Dalam teori perilaku terencara dijelaskan bahwa sikap terhadap perilaku adalah suatu hal penting yang dapat memperkirakan suatu Tindakan, kendati demikian dalam menguji norma subjektif serta mengukur kontrol perilaku persepsian orang perlu untuk mempertimbangka sikap seseorang (Seni \& Ratnadi, 2017). Good governance merupakan ilmu mengenai bagaimana cara perusahaan mengelola perusahaannya dengan baik (Sanchia \& Zen, 2015). Menurut Sastra \& Erawati (2017), good governance merupakan suatu konsep tata kelola perusahaan yang menjelaskan hubungan antara pihak - pihak yang berkepentingan dengan perusahaan dalam upaya perbaikan kinerja perusahaan. Adapun tujuan penerapan good governance pada LPD untuk meningkatkan kinerja keuangan suatu LPD, melindungi kepentingan stakeholders dan meningkatkan kepatuhan terhadap peraturan yang berlaku. Sejalan dengan penelitian yang dilakukan oleh Anggayana \& Wirajaya (2019), Andreana \& Wirajaya (2018) yang mendapatkan 
hasil bahwa prinsip - prinsip GCG berpengaruh positif terhadap kinerja keuangan LPD. Namun berbeda pada penelitian yang dilakukan oleh Sastra \& Erawati (2017) yang mendapatkan hasil bahwa hanya prinsip transparansi dan akuntabilitas yang berpengaruh positif pada kinerja keuangan. Sedangkan prinsip responsibilitas, independensi, dan kewajaran tidak berpengaruh pada kinerja keuangan LPD. Penelitian Nasution (2018) juga mendapat hasil yang berbeda dimana akuntabilitas berpengaruh positif dan signifikan terhadap kinerja keuangan pada pemerintah Provinsi Sumatera Utara sementara prinsip transparansi berpengaruh negatif dan signifikan.

Penerapan prinsip good governance pada LPD masih tergolong lemah yang kemudian menyebabkan penurunan kinerja keuangan LPD yang ditandai dengan banyaknya LPD yang kurang sehat. Terdapat beberapa kasus yang telah dipublikasikan oleh beberapa media infomasi yang memuat mengenai tindakan korupsi yang dilakukan oleh pengurus LPD, salah satunya terjadi di LPD Gerokgak Kabupaten Buleleng yang terjerat kasus korupsi (Rp. 1,2M) yang dilakukan oleh ketua LPD itu sendiri (www.radarbali.jawapos.com, 17 Januari 2020). Berdasarkan kasus tersebut dapat disimpulkan bahwa dalam mewujudkan kinerja keuangan LPD yang terus maju dan berkembang tidak hanya dipengaruhi oleh sistem tata kelola yang baik namun dipengaruhi oleh kompetensi yang di miliki oleh SDM.

Penelitian yang dilakukan oleh Sudiarti \& Juliarsa (2020) menunjukkan bahwa kompetensi sumber daya manusia berpengaruh positif dan signifikan terhadap kualitas laporan keuangan LPD. Semakin tinggi kompetensi sumber daya manusia yang dimiliki, seperti tingkat pengetahuan, keterampilan dan sikap perilaku dalam melaksanakan tugas dan tanggung jawab yang akan cenderung meningkatkan kinerja keuangan yang dihasilkan oleh LPD. Berbeda dengan penelitian (Setyaningdyah et al., 2013) yang menyebutkan bahwa kompetensi sumber daya manusia tidak menjadi prediktor signifikan pada disiplin kerja dan kinerja karyawan. Dengan mengetahui faktor-faktor yang mempengaruhi kinerja keuangan, maka perusahaan dapat terus memperbaiki dan mengatasi persoalan yang dihadapinya sehingga kelangsungan hidup perusahaan dapat di pertahankan.

Transparansi merupakan hal yang penting untuk menjaga rasa percaya masyarakat terhadap LPD. Berdasarkan Theory of Planned Behavior yang menyebutkan bahwa suatu perilaku dilakukan oleh individu karena memiliki niat. Pada LPD, setiap individu memberikan keterbukaan informasi pada krama desa ataupun pengelola LPD tersebut. Penelitian yang dilakukan oleh Anggayana \& Wirajaya (2019) yang menyatakan bahwa transparansi berpengaruh positif terhadap kinerja keuangan, sehingga hipotesis yang bisa dikembangkan sebagai berikut.

$\mathrm{H}_{1}$ : Transparansi berpengaruh positif terhadap kinerja keuangan Lembaga Perkreditan Desa di Kabupaten Badung.

Akuntabilitas adalah kejelasan dari fungsi, struktur, sistem, pelaksanaan, dan pertanggung jawaban sehingga perusahaan dapat dikelola secara efektif. Akuntabilitas merupakan prasyarat yang diperlukan untuk mencapai kinerja yang berkesinambungan (Wibowo \& Gunawan, 2015). Berdasarkan Theory of Planned Behavior pada LPD menentukan prilaku individu untuk 
bertanggungjawab atas kineja secara transparan dan wajar. Penelitian (Wibowo \& Gunawan, 2015) mendapatkan hasil bahwa akuntabilitas berpengaruh terhadap kinerja keuangan LPD, sehingga hipotesis yang bisa dikembangkan adalah sebagai berikut.

$\mathrm{H}_{2}$ : Akuntabilitas berpengaruh positif terhadap kinerja keuangan Lembaga Perkreditan Desa di Kabupaten Badung.

Responsibilitas adalah kesesuaian dan sikap perusahaan dalam mengelola usahanya berdasarkan peraturan undang - undang yang berlaku. Berdasarkan Theory of Planned Behavior pada LPD menentukan sikap individu pada organisasi dalam mengelola organisasi tersebut berdasarkan aturan yang berlaku. Terdapat beberapa penelitian-penelitian sebelumnya mengenai hubungan pengaruh responsibilitas pada kinerja keuangan yaitu penelitian yang dilakukan oleh Andreana \& Wirajaya (2018), Wirawan \& Putri (2018), Anggayana \& Wirajaya (2019) yang mendapatkan hasil yang serupa yaitu ditemukannya pengaruh positif dari responsibilitas terhadap kinerja keuangan, sehingga hipotesis yang bisa dikembangkan sebagai berikut.

$\mathrm{H}_{3}$ : Responsibilitas berpengaruh positif terhadap kinerja keuangan pada Lembaga

Perkreditan Desa di Kabupaten Badung.

Independensi adalah sikap perusahaan saat mengambil keputusan tanpa terikat oleh pihak lain ataupun yang mendominasi. Berdasarkan Theory of Planned Behavior pada LPD digunakan untuk pembentukan sikap organisasi dalam mengambil keputusan tanpa diintervensi pihak manapun. Penelitian yang dilakukan oleh Wirawan \& Putri (2018) menemukan bahwa independensi berpengaruh terhadap kinerja keuangan Koperasi di kabupaten Gianyar, sehingga hipotesis yang bisa dikembangkan sebagai berikut.

$\mathrm{H}_{4}$ : Independensi berpengaruh positif terhadap kinerja keuangan Lembaga Perkreditan Desa di Kabupaten Badung.

Kewajaran adalah keadilan dan kesetaraan oleh pihak perusahaan dalam memenuhi kepentingan dari stakeholders yang ada berdasarkan perjanjian dan peraturan perundang - undangan yang berlaku. Berdasarkan Theory of Planned Behavior dikatakan individu melakukan suatu prilaku karena adanya niat. Pada LPD, setiap individu memberikan kesetaraan dalam memperlakukan nasabahnya serta secara adil memberikan informasi kepada nasabahnya. Penelitian yang dilakukan oleh Sastra \& Erawati (2017) mendapatkan hasil bahwa kewajaran berpengaruh terhadap kinerja keuangan LPD, sehingga hipotesis yang bisa dikembangkan sebagai berikut.

$\mathrm{H}_{5}$ : Kewajaran berpengaruh positif terhadap kinerja keuangan Lembaga Perkreditan Desa di Kabupaten Badung.

Pengetahuan adalah suatu kemampuan yang dimiliki oleh seorang individu yang membentuk wawasan pengetahuan yang komperehensif dalam membentuk sikap dan karakter untuk mencapai tujuan pendidikan nasional. Berdasarkan Theory of Planned Behavior, pada LPD apabila individu memiliki pengetahuan yang memadai akan membantu individu untuk menentukan perilaku dalam menjalankan pekerjaanya. Penelitian yang dilakukan Mahardini \& Miranti (2018) menyebutkan bahwa kompetensi sumber daya manusia berpengaruh positif terhadap kualitas laporan keuangan Pemerintah Provinsi 
Banten Tahun Anggaran 2015, sehingga hipotesis yang bisa dikembangkan sebagai berikut.

$\mathrm{H}_{6}$ : Pengetahuan berpengaruh positif pada kinerja keuangan Lembaga Perkreditan Desa di Kabupaten Badung.

Keterampilan adalah suatu bentuk pengembangan pegawai untuk mampu terampil dalam bidang kerjanya. Berdasarkan Theory of Planned Behavior, pada LPD setiap individu yang memiliki keterampilan akan menerapkannya pada tugas yang dijalankannya. Penelitian yang dilakukan Sudiarti \& Juliarsa (2020) menunjukkan bahwa kompetensi sumber daya manusia berpengaruh positif dan signifikan terhadap kualitas laporan keuangan LPD, sehingga hipotesis yang bisa dikembangkan sebagai berikut.

$\mathrm{H}_{7}$ : Keterampilan berpengaruh positif pada kinerja keuangan Lembaga Perkreditan Desa di Kabupaten Badung.

Sikap adalah manifestasi kepribadian yang ditunjukkan ketika seseorang berinteraksi dengan dengan lingkungannya, dan merupakan tuntutan perilaku yang menyikapi kemampuan kompetensi dengan baik dalam mencapai tujuan. Berdasarkan Theory of Planned Behavior LPD dapat menentukan sikap yang dimiliki individu dalam mengelola organisasi secara jujur dan disiplin. Penelitian yang dilakukan oleh Fadhil (2016) menyebutkan bahwa kompetensi SDM yang terdiri dari pengetahuan, keterampilan dan sikap berpengaruh positif dan signifikan terhadap kinerja pegawai, sehingga hipotesis yang bisa dikembangkan sebagai berikut.

$\mathrm{H}_{8}$ : Sikap berpengaruh positif pada kinerja keuangan Lembaga Perkreditan Desa di Kabupaten Badung.

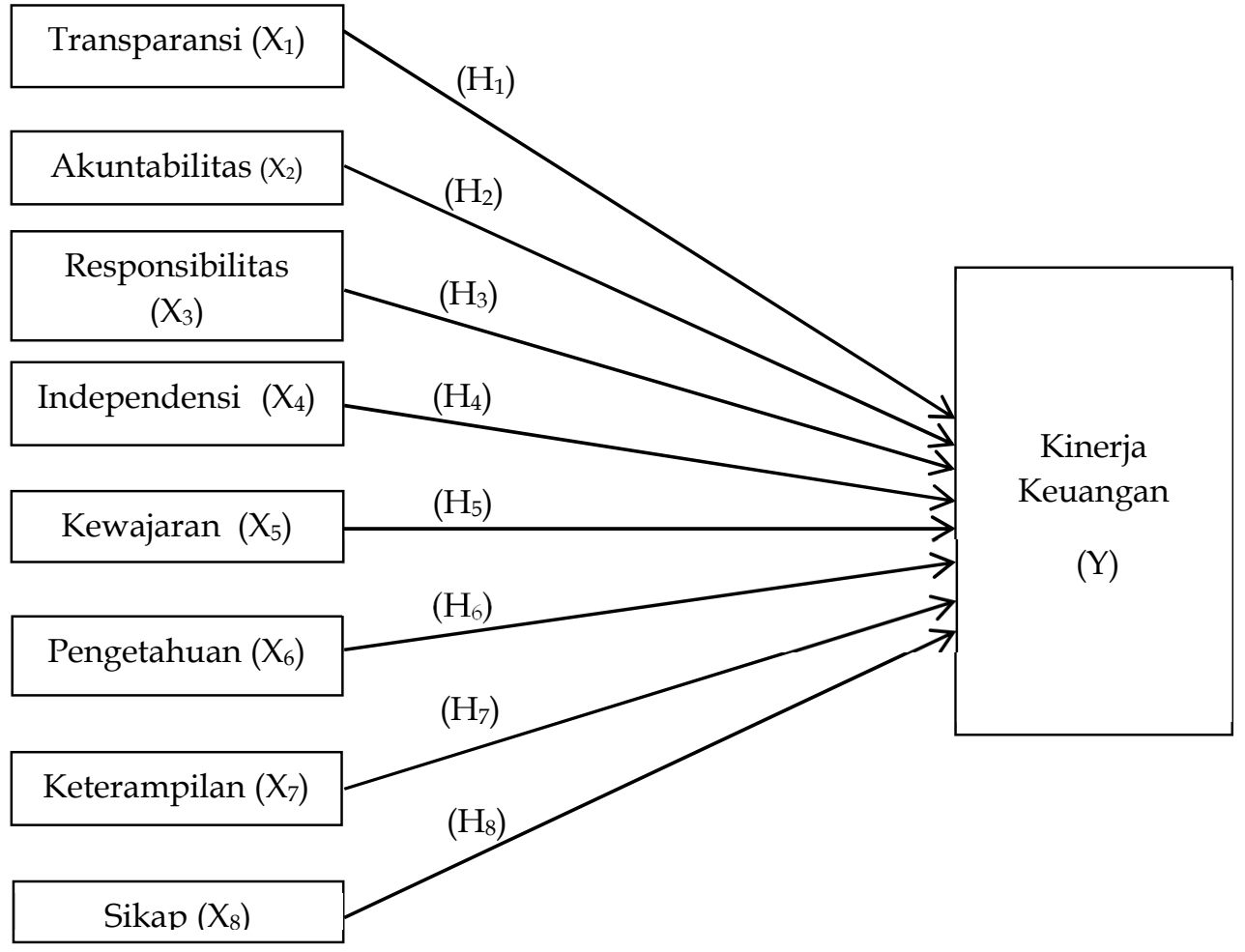

Sumber: Data Penelitian, 2021

\section{Gambar 1. Kerangka Konseptual}




\section{METODE PENELITIAN}

Desain penelitian yang digunakan adalah penelitian kuantitatif berbentuk asosiatif, yang bertujuan untuk mengetahui faktor-faktor yang mempengaruhi kinerja keuangan Lembaga Perkreditan Desa. Penelitian ini dilakukan pada LPD Kabupaten Badung, dikarenakan LPD di Kabupaten Badung merupakan pemilik aset terbesar dari seluruh Kabupaten yang ada di Bali namun kondisi dari LPD yang berada pada kabupaten ini cukup banyak yang tingkat kesehatannya kurang baik. Variabel dependen dalam penelitian ini adalah kinerja keuangan (Y). Variabel independen dalam penelitian ini adalah transparansi $\left(X_{1}\right)$, Akuntabilitas $\left(X_{2}\right)$, Responsibilitas $\left(X_{3}\right)$, Independensi $\left(X_{4}\right)$, Kewajaran $\left(X_{5}\right)$, Pengetahuan $\left(X_{6}\right)$, Keterampilan $\left(X_{7}\right)$, Sikap $\left(X_{8}\right)$. Sumber data dalam penelitian yaitu data primer berupa pengisian kuesioner kepada responden, dan data sekunder berupa daftar nama dan jumlah LPD di Kabupaten Badung, jumlah aset LPD serta laporan tingkat kesehatan LPD Kabupaten Badung.

Populasi dalam penelitian ini adalah LPD yang masih beroperasi di Kabupaten Badung yaitu sebanyak 116 LPD, dengan proporsi menurut kecamatan dimana pada Kecamatan Abiansemal terdapat 33 LPD (28 persen), Mengwi 38 LPD (33 persen), Kuta 21 LPD (18 persen), Petang 24 LPD (21 persen). Teknik pengambilan sampel dalam penelitian ini adalah teknik probability sampling, menggunakan jenis proportionate stratified random sampling. Berdasarkan hasil perhitungan diperoleh sampel sebanyak 90 atau sekitatar 77 persen dari keseluruhan jumlah LPD.

Metode pengumpulan data yang digunakan dalam penelitian ini adalah metode survei dengan menyebarkan kuesioner. Dalam penelitian ini, jawaban kuesioner akan diukur dengan menggunakan skala likert untuk mengukur sikap, pendapat, dan persepsi seseorang atau sekelompok tentang fenomena. Teknik analisis data yang digunakan dalam penelitian ini adalah analisis regresi linier berganda, namun sebelum model regresi digunakan untuk mengujihipotesis, dilakukan uji asumsi klasik terlebih dulu. Berikut rumus persamaan analisis regresi linier berganda, yaitu sebagai berikut.

$Y=\alpha+\beta_{1} X_{1}+\beta_{2} X_{2}+\beta_{3} X_{3}+\beta_{4} X_{4}+\beta_{5} X_{5}+\beta_{6} X_{6}+\beta_{7} X_{7}+\beta_{8} X_{8}+\varepsilon$

Keterangan :

Y : Kinerja keuangan

$\mathrm{X}_{1} \quad$ :Transparansi

$\mathrm{X}_{2}$ : Akuntabilitas

$X_{3} \quad$ : Responsinilitas

$\mathrm{X}_{4} \quad$ : Independensi

$\mathrm{X}_{5}$ : Kewajaran

$\mathrm{X}_{6} \quad$ : Pengetahuan

$\mathrm{X}_{7} \quad$ : Keterampilan

$\mathrm{X}_{8} \quad$ : Sikap

$\beta_{1}-\beta_{8}:$ Koefisien regresi

$\alpha \quad$ : Konsanta

$\varepsilon \quad:$ Standar error 


\section{HASIL DAN PEMBAHASAN}

Penelitian ini dilakukan pada 90 LPD di Kabupaten Badung. Data dikumpulkan dengan menyebarkan langsung kuesioner ke masing - masing LPD sebanyak 270 kuesioner. Jumlah kuesioner yang dikembalikan adalah 261 kuesioner (97 persen) sedangkan sebanyak 9 kuesioner atau 3 LPD yang tidak mengembalikan kuesioner karena kesibukan LPD. Berdasarkan kondisi tersebut hanya 261 kuesioner (97 persen) dari 87 LPD yang dapat diproses lebih lanjut. Hasil dari statistik deskriptif dapat dilihat pada Tabel 1. sebagai berikut:

Tabel 1. Hasil Analisis Statistik Deskriptif

\begin{tabular}{cccccc}
\hline Variabel & N & Minimum & Maksimum & $\begin{array}{c}\text { Rata- } \\
\text { Rata }\end{array}$ & $\begin{array}{c}\text { Deviasi } \\
\text { Standar }\end{array}$ \\
\hline Transparansi & 87 & 10 & 16 & 13,05 & 1,468 \\
Akuntabilitas & 87 & 11 & 16 & 13,21 & 1,302 \\
Responsibilitas & 87 & 8 & 12 & 10,30 & 1,147 \\
Independensi & 87 & 11 & 16 & 13,18 & 1,400 \\
Kewajaran & 87 & 9 & 12 & 9,95 & 1,085 \\
Pengetahuan & 87 & 10 & 16 & 12,99 & 1,329 \\
Keterampilan & 87 & 14 & 20 & 16,72 & 1,694 \\
Sikap & 87 & 12 & 16 & 13,90 & 1,563 \\
Kinerja Keuangan & 87 & 13 & 24 & 19,41 & 1,914 \\
\hline
\end{tabular}

Sumber: Data Penelitian, 2021

Transparansi $\left(X_{1}\right)$ memiliki nilai rata-rata (mean) sebesar 13,05 dengan deviasi standar sebesar 1,468. Hal ini berarti jawaban atas pernyataan pada kuesioner mengindikasikan bahwa transparansi yang dimiliki LPD di Kabupaten Badung cenderung tinggi, serta sebaran data dapat dinyatakan sudah merata. Akuntabilitas $\left(\mathrm{X}_{2}\right)$ memiliki nilai rata-rata (mean) sebesar 13,21 dengan deviasi standar sebesar 1,302. Hal ini berarti jawaban atas pernyataan pada kuesioner mengindikasikan bahwa akuntabilitas yang dimiliki LPD di Kabupaten Badung cenderung tinggi, serta sebaran data dapat dinyatakan sudah merata. Responsibilitas $\left(\mathrm{X}_{3}\right)$ memiliki nilai rata-rata (mean) sebesar 10,30 dengan deviasi standar sebesar 1,147. Hal ini berarti jawaban atas pernyataan pada kuesioner mengindikasikan bahwa responsibilitas yang dimiliki LPD di Kabupaten Badung cenderung tinggi, serta sebaran data dapat dinyatakan sudah merata. Independensi $\left(\mathrm{X}_{4}\right)$ memiliki nilai rata-rata (mean) sebesar 13,18 dengan deviasi standar sebesar 1,400. Hal ini berarti jawaban atas pernyataan pada kuesioner mengindikasikan bahwa independensi yang dimiliki LPD di Kabupaten Badung cenderung tinggi, serta sebaran data dapat dinyatakan sudah merata.

Kewajaran $\left(X_{5}\right)$ memiliki nilai rata-rata (mean) sebesar 9,95 dengan deviasi standar sebesar 1,085. Hal ini berarti jawaban atas pernyataan pada kuesioner mengindikasikan bahwa kewajaran yang dimiliki LPD di Kabupaten Badung cenderung tinggi, serta sebaran data dapat dinyatakan sudah merata. Pengetahuan $\left(\mathrm{X}_{6}\right)$ memiliki nilai rata-rata (mean) sebesar 12,99 ini artinya ada kecenderungan nilai rata-rata mendekati nilai maksimum. Hal ini berarti bahwa berdasarkan jawaban atas pernyataan yang terdapat pada kuesioner variabel pengetahuan, mengindikasikan bahwa pengetahuan yang dimiliki LPD di Kabupaten Badung cenderung tinggi, serta sebaran data berupa jawaban responden pada butir-butir pernyataan pengetahuan dapat dinyatakan sudah 
merata. Keterampilan $\left(X_{7}\right)$ memiliki nilai rata-rata (mean) sebesar 16,72 dengan deviasi standar sebesar 1,694. Hal ini berarti jawaban atas pernyataan pada kuesioner mengindikasikan bahwa keterampilan yang dimiliki LPD di Kabupaten Badung cenderung tinggi, serta sebaran data berupa jawaban responden pada butir-butir pernyataan keterampilan dapat dinyatakan sudah merata. Sikap $\left(\mathrm{X}_{8}\right)$ memiliki nilai rata-rata (mean) sebesar 13,90 dengan deviasi standar sikap sebesar 1,563 . Hal ini berarti jawaban atas pernyataan pada kuesioner mengindikasikan bahwa sikap yang dimiliki LPD di Kabupaten Badung cenderung tinggi, serta sebaran data dapat dinyatakan sudah merata. Kinerja keuangan $(\mathrm{Y})$ memiliki nilai rata-rata (mean) sebesar 19,41 dengan standar deviasi sebesar 1,914. Hal ini berarti jawaban atas pernyataan pada kuesioner mengindikasikan bahwa kinerja keuangan yang dimiliki LPD di Kabupaten Badung cenderung tinggi, serta sebaran data dapat dinyatakan sudah merata.

Model regresi akan lebih tepat digunakan dan menghasilkan perhitungan yang lebih akurat, apabila beberapa asumsi berikut dapat terpenuhi. Uji normalitas ini bertujuan untuk mengetahui apakah residual dari model regresi yang dibuat berdistribusi normal atau tidak. Melalui uji Kolmogorov-Smirnov, jika probabilitas signifikansi nilai residual lebih besar dari 0,05 maka data tersebut dikatakan berdistribusi normal. Hasil uji normalitas dapat dilihat pada Tabel 2.

Tabel 2. Hasil Uji Normalitas

\begin{tabular}{cc}
\hline & Unstandardized Residual \\
\hline $\mathrm{N}$ & 261 \\
Kolmogorov-Smirnov Z & 0,115 \\
Asymp. Sig. (2-tailed) & 0,591 \\
\hline
\end{tabular}

Sumber: Data Penelitian, 2021

Berdasarkan hasil analisis didapat nilai signifikansi sebesar 0,591 yang lebih besar dari 0,05. Oleh karena nilai signifikansi uji Kolmogorov-Smirnov lebih dari 0,05 maka dapat disimpulkan bahwa data yang diuji berdistribusi normal.

Uji multikolinearitas bertujuan untuk menguji apakah dalam satu model regresi ditemukan adanya korelasi antar variabel bebas. Untuk mendeteksi ada atau tidaknya korelasi antar variabel bebas dapat dilihat dari nilai tolerance dan nilai variance inflation factor (VIF). Jika nilai tolerance lebih dari 10 persen atau VIF kurang dari 10, maka dapat dikatakan model telah bebas dari multikolinearitas. Hasil uji multikolinieritas dapat dilihat pada Tabel 3.

Tabel 3. Hasil Uji Multikolinearitas

\begin{tabular}{ccc}
\hline Variabel & \multicolumn{2}{c}{ Collinearity Statistic } \\
\cline { 2 - 3 } & Tolerance & VIF \\
\hline Transparansi $\left(X_{1}\right)$ & 0,646 & 1,547 \\
Akuntabilitas $\left(X_{2}\right)$ & 0,591 & 1,692 \\
Responsibilitas $\left(X_{3}\right)$ & 0,594 & 1,685 \\
Independensi $\left(X_{4}\right)$ & 0,570 & 1,756 \\
Kewajaran $\left(X_{5}\right)$ & 0,649 & 1,540 \\
Pengetahuan $\left(X_{6}\right)$ & 0,642 & 1,558 \\
Keterampilan $\left(X_{7}\right)$ & 0,529 & 1,889 \\
Sikap $\left(X_{8}\right)$ & 0,642 & 1,558 \\
\hline
\end{tabular}

Sumber: Data Penelitian, 2021

Berdasarkan hasil uji multikolinearitas diperoleh nilai tolerance dari masingmasing variabel lebih besar dari 0,10 da nilai VIF dari masing-masing variabel 
lebih kecil dari 10, sehingga dapat dinyatakan bahwa variabel bebas pada model regresi yang ada, tidak terjadi gejala multikolinearitas.

Uji heteroskedastisitas bertujuan menguji apakah dalam regresi terjadi ketidaksamaan varians dari residual satu pengamatan ke pengamatan yang lain (Ghozali, 2016: 139). Pengujian pada penelitian ini menggunakan Uji Glejser, model ini dilakukan dengan meregresikan nilai absolut residual dengan variabel bebas. Hasil uji heteroskedastisitas disajikan dalam Tabel 4.

Tabel 4. Hasil Uji Heteroskedastisitas

\begin{tabular}{cc}
\hline Variabel & Sig. \\
\hline Transparansi $\left(X_{1}\right)$ & 0,958 \\
Akuntabilitas $\left(X_{2}\right)$ & 0,282 \\
Responsibilitas $\left(X_{3}\right)$ & 0,618 \\
Independensi $\left(X_{4}\right)$ & 0,250 \\
Kewajaran $\left(X_{5}\right)$ & 0,097 \\
Pengetahuan $\left(X_{6}\right)$ & 0,934 \\
Keterampilan $\left(X_{7}\right)$ & 0,088 \\
Sikap $\left(X_{8}\right)$ & 0,126 \\
\hline
\end{tabular}

Sumber: Data Penelitian, 2021

Berdasarkan hasil uji heteroskedastisitas diperoleh nilai Sig. dari masingmasing variabel lebih besar dari 0,05 sehingga dapat disimpulkan bahwa variabel bebas pada model regresi yang ada, tidak terjadi gejala heteroskedastisitas. Setelah melakukan uji asumsi klasik maka dapat dilakukan analisis regresi linear berganda. Hasil dari analisis regresi linear berganda padapenelitian ini dapat dilihat pada Tabel 5 .

Tabel 5. Hasil Analisis Regresi Linear Berganda

\begin{tabular}{|c|c|c|c|c|c|}
\hline \multirow[t]{2}{*}{ Model } & \multicolumn{2}{|c|}{$\begin{array}{c}\text { Unstandardized } \\
\text { coefficients }\end{array}$} & \multirow{2}{*}{$\begin{array}{c}\text { Standardized } \\
\text { coefficients }\end{array}$} & \multirow[t]{2}{*}{$t$} & \multirow[t]{2}{*}{ Sig. } \\
\hline & $B$ & Std. Error & & & \\
\hline 1 (Constant) & 9,326 & 1,381 & & 6,218 & 0,000 \\
\hline Transparansi & 0,062 & 0,072 & 0,031 & 0,362 & 0,015 \\
\hline Akuntabilitas & 0,071 & 0,112 & 0,024 & 0,281 & 0,007 \\
\hline Responsibilitas & 0,213 & 0,125 & 0,089 & 1,358 & 0,021 \\
\hline Independensi & 0,052 & 0,086 & 0,032 & 0,387 & 0,016 \\
\hline Kewajaran & 0,135 & 0,146 & 0,053 & 0,734 & 0,032 \\
\hline Pengetahuan & 0,186 & 0,089 & 0,125 & 1,602 & 0,013 \\
\hline Keterampilan & 0,288 & 0,096 & 0,252 & 2,976 & 0,003 \\
\hline Sikap & 0,412 & 0,086 & 0,284 & 4,134 & 0,000 \\
\hline
\end{tabular}

Variabel Dependen : Kinerja keuangan

Sumber: Data Penelitian, 2021

Berdasakan Tabel 5, menunjukkan nilai koefisien regresi dari variabel bebas dan nilai konstanta variabel terikat, maka dapat diperoleh persamaan regresi linear berganda sebagai berikut.

$$
\begin{aligned}
Y= & 9,326+0,062 X_{1}+0,071 X_{2}+0,213 X_{3}+0,052 X_{4}+0,135 X_{5}+0,186 X_{6}+0,288 \\
& X_{7}+0,412 X_{8}+\varepsilon
\end{aligned}
$$

Nilai koefisien determinasi $\left(R^{2}\right)$ menunjukkan seberapa jauh kemampuan variabel bebas dalam menjelaskan variasi variabel terikat. Dalam penelitian ini menggunakan nilai Adjusted $\mathrm{R}^{2}$. Berdasarkan hasil perhitungan diperoleh nilai dari Adjusted $\mathrm{R}^{2}$ adalah sebesar 0,326 atau 32,6 persen, dimana memiliki arti bahwa 
32,6 persen variansi kinerja keuangan dipengaruhi oleh variansi transparansi, akuntabilitas, responsibilitas, independensi, kewajaran, pengetahuan, keterampilan, dan sikap, sedangkan sisanya yang sebesar 67,4 persen dipengaruhi oleh variabel-variabel lain yang tidak dijelaskan dalam penelitian ini.

Uji kelayakan model (Uji F) dilakukan dengan membandingkan tingkat signifikansi masing-masing variabel bebas secara bersama-sama dengan taraf signifikannya yaitu $\alpha=0,05$. Berdasarkan hasil pengujian diperoleh nilai $F_{h i t u n g}$ sebesar 13,963 dengan signifikansi sebesar 0,000. Hal ini menunjukkan bahwa signifikansi pada Uji F nilainya lebih kecil dari 0,05 (5 persen), sehingga dapat disimpulkan bahwa model regresi yang dibuat layak digunakan untuk menjelaskan pengaruh transparansi, akuntabilitas, responsibilitas, independensi, kewajaran, pengetahuan, keterampilan, dan sikap terhadap kinerja keuangan.

Hasil uji pengaruh transparansi pada kinerja keuangan $\left(\mathrm{H}_{1}\right)$ menunjukkan bahwa transparansi memiliki nilai signifikansi sebesar 0,015 dengan thitung bernilai positif sebesar 0,362. Nilai signifikansi variabel sebesar 0,015 lebih kecil dari taraf signifikansi sebesar 0,05 (5 persen) yang mengindikasikan bahwa $\mathrm{H}_{1}$ diterima, yang berarti bahwa secara parsial transparansi berpengaruh positif terhadap kinerja keuangan. Hal ini menunjukan bahwa semakin tinggi tingkat transparansi dalam mengungkapkan informasi yang material dan relevan mengenai keadaan LPD maka kinerja keuangan yang dihasilkan akan semakin meningkat, sebaliknya semakin rendah penerapan transparansi pada LPD di Kabupaten Badung maka kinerja keuangan yang dihasilkan juga akan semakin menurun. Hasil penelitian ini mendukung Theory of Planned Behavior, dimana dikatakan individu melakukan suatu prilaku karena adanya niat. Pada LPD, setiap individu memberikan keterbukaan informasi pada krama desa ataupun pengelola LPD tersebut. Temuan ini sejalan dengan penelitian yang dilakukan oleh Anggayana \& Wirajaya (2019) serta Wirawan \& Putri (2018) bahwa transparansi berpengaruh positif terhadap kinerja keuangan.

Hasil uji pengaruh akuntabilitas pada kinerja keuangan $\left(\mathrm{H}_{2}\right)$ menunjukkan bahwa akuntabilitas memiliki nilai signifikansi sebesar 0,007 dengan $t_{\text {hitung }}$ bernilai positif sebesar 0,281 . Nilai signifikansi variabel sebesar 0,007 lebih kecil dari taraf signifikansi sebesar 0,05 (5 persen) yang mengindikasikan bahwa $\mathrm{H}_{2}$ diterima, yang berarti bahwa secara parsial akuntabilitas berpengaruh positif terhadap kinerja keuangan. Kejelasan fungsi dan pertanggungjawaban dalam LPD, maka akan semakin baik pengelolaan dari LPD, sehingga kinerja keuangan akan meningkat. Hasil penelitian ini mendukung Theory of Planned Behavior, dimana pada LPD menentukan prilaku individu untuk bertanggungjawab atas kinerja secara transparan dan wajar (Wirawan \& Putri, 2018). Dengan demikian niat berperilaku ang dimiliki pengurus LPD yang mempengaruhi kinerja keuangan (Suryawirawan, 2019). LPD yang mampu membentuk badan pengawas yang berpengalaman, lalu membentuk dan menetapkan fungsi dan wewenang dari masing-masing pengurus LPD maka hal tersebut akan mampu memberikan kontribusi yang signifikan untuk meningkatkan prinsip akuntabilitas yang akan berdampak pada meningkatnya kinerja keuangan. Temuan ini sejalan dengan penelitian yang dilakukan oleh Andreana \& Wirajaya (2018) serta penelitian dari Sastra \& Erawati (2017) bahwa akuntabilitas berpengaruh positif terhadap kinerja keuangan. 
Hasil uji pengaruh responsibilitas pada kinerja keuangan $\left(\mathrm{H}_{3}\right)$ menunjukkan bahwa responsibilitas memiliki nilai signifikansi sebesar 0,021 dengan $t_{\text {hitung }}$ bernilai positif sebesar 1,338. Nilai signifikansi variabel sebesar 0,021 lebih kecil dari taraf signifikansi sebesar 0,05 (5 persen) yang mengindikasikan bahwa $\mathrm{H}_{3}$ diterima, yang berarti bahwa secara parsial responsibilitas berpengaruh positif terhadap kinerja keuangan. Hal ini menunjukan bahwa kepatuhan LPD terhadap hukum dan bertanggungjawab terhadap masyarakat dan lingkungan LPD maka akan membuat masyarakat lebih percaya dan tertarik untuk melakukan transaksi di LPD yang akan mempengaruhi kinerja keuangan LPD. Hasil penelitian ini mendukung Theory of Planned Behavior, dimana pada LPD menentukan sikap individu pada organisasi dalam mengelola organisasi tersebut berdasarkan aturan yang berlaku. LPD di Kabupaten Badung yang mampu mempertimbangkan tanggungjawab sosial, menghindari penyalahgunaan kekuasaan, profesional dan mematuhi etika serta menjadikan lingkungan bisnis yang baik, maka hal tersebut akan mampu memberikan kontribusi yang signifikan untuk meningkatkan prinsip responsibilitas yang akan berdampak pada meningkatnya kinerja keuangan. Temuan ini sejalan dengan penelitian yang dilakukan oleh Andreana \& Wirajaya (2018), Wirawan \& Putri (2018), Prayidyaningrum \& Djamaludin (2016) bahwa responsibilitas berpengaruh posotif terhadap kinerja keuangan.

Hasil uji pengaruh independensi pada kinerja keuangan $\left(\mathrm{H}_{4}\right)$ menunjukkan bahwa independensi memiliki nilai signifikansi sebesar 0,016 dengan thitung bernilai positif sebesar 0,387. Nilai signifikansi variabel sebesar 0,016 lebih kecil dari taraf signifikansi sebesar 0,05 (5 persen) yang mengindikasikan bahwa $\mathrm{H}_{4}$ diterima, yang berarti bahwa secara parsial independensi berpengaruh positif terhadap kinerja keuangan. Semakin independen LPD dalam pengelolaannya, maka LPD akan terbebas dari kepentingan berbagai pihak yang merugikan, sehingga LPD akan mampu meningkatkan kinerja keuangan kearah yang lebih baik. Hasil penelitian ini mendukung Theory of Planned Behavior, dimana pada LPD digunakan untuk pembentukan sikap organisasi dalam mengambil keputusan tanpa diintervensi pihak manapun (Sofyan, 2019). Apabila LPD mampu menggunakan tenaga ahli di segala bidang, tidak melibatkan pengaruh pihak luar, menghindari benturan kepentingan, serta menjalankan aktivitas LPD yang baik dan dinamis maka hal tersebut akan mampu memberikan kontribusi yang signifikan untuk meningkatkan prinsip independensi yang akan berdampak pada meningkatnya kinerja keuangan (Sofyan, 2019). Temuan ini sejalan dengan penelitian yang dilakukan oleh (Anggayana \& Wirajaya, 2019) serta penelitian dari (Wirawan \& Putri, 2018) bahwa independensi berpengaruh posotif terhadap kinerja keuangan.

Hasil uji pengaruh kewajaran pada kinerja keuangan $\left(\mathrm{H}_{5}\right)$ menunjukkan bahwa kewajaran memiliki nilai signifikansi sebesar 0,032 dengan $t_{\text {hitung }}$ bernilai positif sebesar 0,734. Nilai signifikansi variabel sebesar 0,032 lebih kecil dari taraf signifikansi sebesar 0,05 (5 persen) yang mengindikasikan bahwa $\mathrm{H}_{5}$ diterima, yang berarti bahwa secara parsial kewajaran berpengaruh positif terhadap kinerja keuangan. Hal ini menunjukan bahwa jika dalam pengelolaan LPD selalu berlandaskan kewajaran dan kesetaraan, maka kinerja keuangan LPD juga akan meningkat. Hasil penelitian ini mendukung Theory of Planned Behavior, dimana 
dikatakan individu melakukan suatu prilaku karena adanya niat. Pada LPD, setiap individu memberikan kesetaraan dalam memperlakukan nasabahnya serta secara adil memberikan informasi kepada nasabahnya (Suprapto, 2019). Temuan ini sejalan dengan penelitian yang dilakukan oleh (Andreana \& Wirajaya, 2018) serta penelitian dari (Sastra \& Erawati, 2017) bahwa kewajaran berpengaruh posotif terhadap kinerja keuangan.

Hasil uji pengaruh pengetahuan pada kinerja keuangan $\left(\mathrm{H}_{6}\right)$ menunjukkan bahwa pengetahuan memiliki nilai signifikansi sebesar 0,013 dengan $t_{\text {hitung }}$ bernilai positif sebesar 1,602. Nilai signifikansi variabel sebesar 0,013 lebih kecil dari taraf signifikansi sebesar 0,05 (5 persen) yang mengindikasikan bahwa $\mathrm{H}_{6}$ diterima, yang berarti bahwa secara parsial pengetahuan berpengaruh positif terhadap kinerja keuangan. Semakin tinggi tingkat pengetahuan yang dimiliki karyawan pada LPD di Kabupaten Badung maka kinerja keuangan yang dihasilkan akan semakin meningkat, sebaliknya semakin rendah pengetahuan yang di miliki karyawan pada LPD di Kabupaten Badung maka kinerja keuangan yang dihasilkan juga akan semakin menurun. Hasil penelitian ini mendukung Theory of Planned Behavior, hal ini menunjukkan apabila individu memiliki pengetahuan yang memadai akan membantu individu untuk menentukan perilaku dalam menjalankan pekerjaanya (Talreja \& Shivappa, 2016). Pengetahuan dari karyawan sangat di perlukan dalam menjalankan sebuah LPD terutama dalam menghasilkan kinerja keuangan yang baik.

Hasil uji pengaruh keterampilan pada kinerja keuangan $\left(\mathrm{H}_{7}\right)$ menunjukkan bahwa keterampilan memiliki nilai signifikansi sebesar 0,003 dengan $t_{\text {hitung }}$ bernilai positif sebesar 2,976. Nilai signifikansi variabel sebesar 0,003 lebih kecil dari taraf signifikansi sebesar 0,05 (5 persen) yang mengindikasikan bahwa $\mathrm{H}_{7}$ diterima, yang berarti bahwa secara parsial keterampilan berpengaruh positif terhadap kinerja keuangan. Semakin tinggi tingkat keterampilan yang dimiliki karyawan pada LPD di Kabupaten Badung maka kinerja keuangan yang dihasilkan akan semakin meningkat, sebaliknya semakin rendah keterampilan yang di miliki karyawan pada LPD di Kabupaten Badung maka kinerja keuangan yang dihasilkan juga akan semakin menurun (Suryawirawan, 2019). Hasil penelitian ini mendukung Theory of Planned Behavior, dimana pada LPD setiap individu yang memiliki keterampilan akan menerapkannya pada tugas yang dijalankannya.

Hasil uji pengaruh sikap pada kinerja keuangan $\left(\mathrm{H}_{8}\right)$ menunjukkan bahwa sikap memiliki nilai signifikansi sebesar 0,000 dengan $t_{\text {hitung }}$ bernilai positif sebesar 4,134. Nilai signifikansi variabel sebesar 0,000 lebih kecil dari taraf signifikansi sebesar 0,05 (5 persen) yang mengindikasikan bahwa $\mathrm{H}_{8}$ diterima, yang berarti bahwa secara parsial sikap berpengaruh positif terhadap kinerja keuangan Semakin baik sikap yang dimiliki karyawan pada LPD di Kabupaten Badung maka kinerja keuangan yang dihasilkan akan semakin meningkat, sebaliknya semakin buruk sikap yang di miliki karyawan pada LPD di Kabupaten Badung maka kinerja keuangan yang dihasilkan juga akan semakin menurun (Yahaya et al., 2019). Hasil penelitian ini mendukung Theory of Planned Behavior, dimana LPD dapat menentukan sikap yang dimiliki individu dalam mengelola organisasi secara jujur dan disiplin. 


\section{SIMPULAN}

Berdasarkan hasil penelitian yang diperoleh melalui pengujian statistik dan pembahasan seperti yang telah diuraikan sebelumnya, maka dapat disimpulkan bahwa variabel transparansi, akuntanbilitas, responsibilitas, independensi, kewajaran, pengetahuan, keterampilan, dan sikap berpengaruh positif terhadap kinerja keuangan LPD di Kabupaten Badung. Penerapan prinsip good governance dapat membantu memberikan keterbukaan informasi keadaan LPD, meningkatkan kepercayaan kepada pengurus LPD, serta memberikan dampak terhadap pertumbuhan LPD dengan mematuhi segala peraturan yang ada. Kompetensi sumber daya manusia yang ditemukan mendukung Theory of Planned Behavior dimana sikap yang diambil akan mempengaruhi prilaku kerjanya.

Adapun saran-saran yang dapat diberikan peneliti terkait hasil penelitian yaitu kepada LPD untuk lebih meningkatkan nilai kewajaran dan kesetaraan bagi pengurus LPD dalam menjalankan pekerjaanya dengan mampu menerapkan aturan perusahaan yang wajar dalam memberikan informasi-informasi serta memberikan pelayanan yang sama bagi seluruh nasabah yang ada tanpa melihat status sosial yang mereka miliki. Meningkatkan nilai responsibilitas pada setiap pengurus LPD yaitu dengan mempertimbangkan tanggungjawab sosial, menghindari penyalahgunaan kekuasaan, profesional dan mematuhi etika. Bagi peneliti selanjutnya diharapkan dapat memperluas ruang lingkup wilayah penelitian tidak hanya pada Kabupaten Badung saja, melainkan mencakup lingkup daerah yang lebih luas sampai seluruh Provinsi Bali, sehingga dapat mewakili populasi dengan jumlah yang lebih besar.

\section{REFERENSI}

Andreana, M. O. C., \& Wirajaya, I. G. A. (2018). Pengaruh Transparancy, Accountability, Responsibility, Independency, dan Fairness Pada Kinerja Keuangan Lembaga Perkreditan Desa. E-Jurnal Akuntansi Universitas Udayana, 23(2),

27. https://doi.org/https://doi.org/10.24843/EJA.2018.v23.i02.p19

Andriana, A., \& Panggabean, R. R. (2017). The Effect of Good Corporate Governance and Environmental Performance on Financial Performance of the Proper Listed Company on Indonesia Stock Exchange. Binus Business Review, 8(1), 8. https://doi.org/10.21512/bbr.v8i1.1757

Anggayana, I. P. N., \& Wirajaya, I. G. A. (2019). Pengaruh Prinsip-Prinsip Good Governance Dan Budaya Organisasi Terhadap Kinerja Keuangan Lembaga Perkreditan Desa Kota Denpasaro Title. E-Jurnal Akuntansi Universitas Udayana, 298(1),

17. https://doi.org/https://doi.org/10.24843/EJA.2019.v29.i01.p21

Fadhil, M. (2016). Pengaruh Kompetensi Sumber Daya Manusia Terhadap Kinerja Pegawai Pada Balai Latihan Kerja Industri Makassar. Jurnal Perspektif, 01(01), 12.

Ghozali, I. (2016). Aplikasi analisis Multivariete dengan program IBM SPSS 23 (edisi 8). Cetakan ke VIII. Semarang: Badan Penerbit Universitas Diponegoro, 96.

Mahaendrayasa, P. K. A., \& Putri, I. G. A. M. A. D. (2017). Pengaruh PrinsipPrinsip Good Corporate Governance Terhadap Kinerja keuangan Lembaga 
Perkreditan Desa (LPD) di Kota Denpasar. E-Jurnal Akuntansi Universitas Udayana, 21(2), 26. https:/ / doi.org/10.24843/EJA.2017.v21.i02.p04

Mahardini, N. Y., \& Miranti, A. (2018). Dampak Penerapan Standar Akuntansi Pemerintahan dan Kompetensi Sumber Daya Manusia Pada Kualitas Laporan Keuangan Pemerintah Provinsi Banten Tahun Anggaran 2015. Jurnal Akuntansi, 5, 11.

Nasution, D. A. D. (2018). Analisis Pengaruh Pengelolaan Keuangan Daerah, Akuntabilitas dan Transparansi Terhadap Kinerja Keuangan Pemerintah. Jurnal Studi Akuntansi \& Keuangan, 2(3), 149-162.

Nuryana, Y., \& Surjandari, D. A. (2019). The Effect of Good Corporate Governance Mechanism, and Earning Management on Company Financial Performance. Global Journal of Management and Business Research: D Accounting and Auditing, 19(1), 14.

Ozkan, N., Cakan, S., \& Kayacan, M. (2016). Intellectual Capital and Financial Performance: A Study of the Turkish Banking Sector. Borsa Istanbul Review. https://doi.org/10.1016/j.bir.2016.03.001

Paniagua, J., Rivelles, R., \& Sapena, J. (2018). Corporate governance and financial performance: The role of ownership and board structure. Journal of Business Research, 89 ,

6. https://doi.org/https://doi.org/10.1016/j.jbusres.2018.01.060

Prayidyaningrum, S., \& Djamaludin, M. (2016). Theory of Planned Behavior to Analyze the Intention to Use the Electronic Money. Journal of Consumer Sciences, 01(02), 1-12.

Sadiartha, A. A. N. G. (2017). Lembaga perkreditan desa sebagai penopang keajegan budaya ekonomi masyarakat Bali. Jurnal Kajian Bali, 7(2), 18. https://doi.org/https://doi.org/10.1098/rspb.2007.0281

Sanchia, M. I., \& Zen, T. S. (2015). Impact Of Good Corporate Governance In Corporate Peformance. International Journal of Management and Applied Science, 1(9), 5.

Sandraningsih, N. K. B., \& Putri, I. G. A. M. A. D. (2015). Pengaruh Prinsip-Prinsip Good Corporate Governance Pada Kinerja Keuangan Lembaga Perkreditan Desa Kecamatan Abiansemal. E-Jurnal Akuntansi Universitas Udayana, 11(3), 16.

Sastra, I. M. B., \& Erawati, N. M. A. (2017). Pengaruh Penerapan Prinsip-Prinsip Good Corporate Governance dan Budaya Tri Hita Karana Pada Kinerja Keuangan. E-Jurnal Akuntansi Universitas Udayana, 19(1), 31.

Seni, N. N. A., \& Ratnadi, N. M. D. (2017). Theory Of Planned Behavior Untuk Memprediksi Niat Berinvestasi. E-Jurnal Ekonomi Dan Bisnis Universitas Udayana, 6(12), 4043-4068.

Setyaningdyah, E., Nimran, U., \& Armanu, K. (2013). The Effects of Human Resource Competence, Organizational commitment and Transactional Leadership on Work Discipline, Job Satisfaction and Employee's Performance. Interdisciplinary Journal of Contemporary Research in Business, $5(4), 140-153$.

Sofyan, M. (2019). Analysis Financial Performance Of Rural Bank In Indonesia. International Journal of Economics, Business and Accounting Research, 3(3). http://jurnal.stie-aas.ac.id/index.php/IJEBAR 
Sudiarti, N. W., \& Juliarsa, G. (2020). Pengaruh Kompetensi Sumber Daya Manusia dan Locus of Control terhadap Kualitas Laporan Keuangan LPD. E-Jurnal Akuntansi, 30(7), 1725-1737.

Suprapto, Y. (2019). Analysis the impact of Good Corporate Governance Towards Profitability of Manufacturing Companies Listed on indonesia Stock Exchange. Jurnal Ekonomi \& Ekonomi Syariah, 2(1).

Suryawirawan, O. A. (2019). Teory of Planned Behavior Approach and Gender Di erences on Students' Intention to Practice Online Business. Jurnal Dinamika Manajemen, 10(2), 138-147. https:/ /doi.org/DOI: 10.15294/jdm.v10i2.19398

Talreja, J., \& Shivappa. (2016). Financial performance analysis of selected banks using CAMEL Model. International Journal in Management and Social Science, 04(06).

Wibowo, W., \& Gunawan, H. M. (2015). Implementing Good Corporate Governance in Indonesia: A Strategic Approach. Journal of Accounting Business E Management, 22(1), 29-45.

Wirawan, A. A. G. B. P., \& Putri, I. G. A. M. A. D. (2018). Pengaruh Penerapan Prinsip-Prinsip GCG dan Manajemen Risiko Pada Kinerja Keuangan Koperasi di Kabupaten Gianyar. E-Jurnal Akuntansi Universitas Udayana, 23(3), 28. https://doi.org/https:/ / doi.org/10.24843/EJA.2018.v23.i03.p07

Yahaya, R., Zainol, Z., \& Osman, J. H. (2019). The Effect of Financial Knowledge and Financial Attitudes on Financial Behavior among University Students. International Journal of Academic Research in Business and Social Sciences, 9(8), 22-32. https:// doi.org/10.6007/IJARBSS/v9-i8/6205 